\title{
IMPACT OF MINANGKABAU'S OUT MIGRATION: MERANTAU TO HOUSEHOLD LABOR ALLOCATION IN WEST SUMATRA, INDONESIA
}

\author{
Afrizal Roni ${ }^{1 *}$, Rizkiyah Noor ${ }^{2}$, Ismawati lis ${ }^{1}$ \\ ${ }^{1}$ State Agricultural Polytechnic of Payakumbuh,Indonesia \\ ${ }^{2}$ University of Antakusuma, Central Kalimantan, Indonesia \\ *E-mail: iesmawati08@gmail.com
}

\begin{abstract}
Merantau is a unique form of outmigration in Minangkabau communities. The Minangkabau's strong tendency to migration as a rite de passages especially for young men. They migrate from rural areas to looking for experience, prosperity and education. Its also places a heavier burden on household left behind to make up for lost local labor. The impact of outmigration on agriculture, especially on household left behind has long been debated. Thus identifiying the impact of migration on household in rural origin is an open empirical questio. The main purpose of this paper is to analyse impact of merantau to household left-behind labor allocation in on-farm, off-farm and non-farm activity. The paper uses treatment regression techniques to asses impact merantau on household labor allocation. The result provide that merantau contributes to increase hired labor on paddy farming. Paddy farming operations used $89 \%$ hired labor. Merantau reduce labor force participation for household members left behind and increase non-farm activity. Base on the findings, this study contributions to the literature by providing a wider understanding of labor supply decisions in rural household that have migrant and receive financial transfers.
\end{abstract}

\section{KEY WORDS}

Out migration, merantau, minangkabau, paddy farming, labor allocation.

Indonesia is the world's archipelagic country with five major islands among more than 30.000 of islands. Its inhabited by more than three hundred ethnic societies. This condition has been conducive to outmigration between and beyond the islands. The Minangkabau society, one of the largest matrilineal society, have been noted for a high level of outmigration called merantau. Its means voluntary migration from homeland to other places with the aim of earning a living or seeking further knowledge or experience (Naim, 1979). Recently Minangkabau society are found throughout almost in the regions of Indonesia.

The type of merantau is mainly from rural to urban areas. As a typically rural areas, agriculture sector has long been considered to play important role in West Sumatra's economic development. In this province, where paddy farming is dominant, most people especially in rural areas make a living and depends from it. Programmes for increased paddy production is focused on intensification, diversification, expantion and implementation of new technology. Among the obstacles paddy farming faced were land degradation, technological and infrastructure shortcomings, poor financial support and loss empoyment because of outmigration. In paddy production, access to labor very substantially

Perantau, Minangkabau migrants, do not always move with their entire family such as spouse, children and parents. In addition places a heavier burden on household left behind to make up for lost employment. The impact of outmigration on agriculture, especially on household left behind has long been debated. Thus identifiying the impact of migration on household in rural origin is an open empirical question. On the one hand, outmigration through financial transfers, positively to increasing household income (William, 2007; McCarthy,2006; Adam, 1996; Cadwell, 1968), make available capital stock in agricultural production (Black, 1993) and reducing poverty (Acharya and Gonzales, 2012). On the other hand, the physical absence of the migrant may have multiple adverse effects on family member's education, health, labor supply and social status (Démurger, 2015), reducing farm production (Rozelle et.al, 1999; Maharjan, 2013; Taylor and deBrauw, 2003) and labor 


\section{RESULTS AND DISCUSSION}

Determinant of merantau described by number of perantau and financial transfers (refers to remittances). Minangkabau's perantau is generally highly concern for welfare of their family and rural origin. They send financial transfers through friends, the post office, bank or visiting homeland.

Impact Merantau On-Farm Labor Allocation. Table.2 presents parameter estimated. On-farm labor allocation consist for household labor and hired labor. The number of perantau has negatif impact on men's household labor and positif impact on women's hired labor as expected. Raising in household labor supply due to migration reducing men's household hours worked on paddy farming, on the contrary increasing number of women's hired labor.

The negatif sign of $\mathrm{HHL}_{m}$ variable, suggested related to ageing phenomenon in agriculture areas. According to Fan et.al (2014) findings alteration demographic composition of the agricultural work force in US. The average worker today is older and more likely to be female. They hipothesized that such worker might be less likely to migrate. Kreager (2006) said that in Rao-Ra, one of the higher level migration in Tanah Datar district, activity merantau was change social structure and ageing phenomenon. This indicated from positif sign in household head age (HHA) on men's hired labor. The value of HHA coefficient is 3.58 means raising on 1\% HHA will be increase men's hired labor 3.58 hours worked.

Futhermore outmigration of family members including young men was independently associated with raising leisure time allocation for parents or non-farm activity any else. Financial transfers perceived support household well-being and reducing on-farm labor allocation. William (2007) called this phenomenon as "moral hazard" such as impact of flows financial transfers from migrant or perantau to family left behind.

Based on the data ( show in Figure 1) can descibing why men's household labor decreasing ? We suggest it associated with sort of paddy operations. Involvement of men's household labor in all of paddy operation is less. Generally they workfield on a part of land preparation (such as slashing or dibbling bar) and fertilization. Plowing land used tractor machine and harvesting was worked by men's hired labor. On the other hand both women's household and hired doing transplanting, weeding, fertilization and also harvesting. This study reveal that migration make "agricultural feminism" as supported by Sifelani (2009), Katz (2003) and Schmook (2008). With the result, hired labor were contribution on paddy operations about $89 \%$ and household labor $11 \%$.

Table 2 - Estimation Result of Equation parameter: Labor Allocation on Paddy Farming

\begin{tabular}{|c|c|c|c|c|}
\hline \multirow[b]{2}{*}{ Explanatory variables } & \multicolumn{4}{|c|}{ Parameter Value } \\
\hline & $\begin{array}{c}\text { Men's Household } \\
\text { Labor }\end{array}$ & $\begin{array}{c}\text { Women's Household } \\
\text { Labor }\end{array}$ & $\begin{array}{l}\text { Men's Hired } \\
\text { Labor }\end{array}$ & $\begin{array}{c}\text { Women's Hired } \\
\text { Labor }\end{array}$ \\
\hline Intercept & $-1.20^{\mathrm{ns})}$ & $1.80^{* \star}$ & $0.27^{\mathrm{ns})}$ & $-0.63^{\mathrm{ns})}$ \\
\hline Men'sHousehold labor $\left(\mathrm{HHL}_{\mathrm{m}}\right)$ & & $1.41^{\mathrm{ns})}$ & $-0.44^{\mathrm{ns})}$ & \\
\hline $\begin{array}{l}\text { Women's Household Labor }\left(\mathrm{HHL}_{\mathrm{w}}\right) \\
\text { Men's Hired labor }\left(\mathrm{HL}_{\mathrm{m}}\right)\end{array}$ & & & & $\begin{array}{l}-2.16^{* *} \\
-0.14^{\text {ns) }}\end{array}$ \\
\hline Land size(LS) & $0.41^{\mathrm{ns})}$ & $-0.90^{\mathrm{ns})}$ & $2.91^{* * *}$ & $4.02^{* * *}$ \\
\hline Agriculture wage (W) & $-0.25^{\mathrm{ns})}$ & & $-2.19^{* *}$ & $0.84^{n s)}$ \\
\hline Number of perantau (NM) & $-1.53^{*}$ & & $0.14^{\mathrm{ns})}$ & $2.37^{* *}$ \\
\hline Paddy Price (PR) & $2.47^{* *}$ & $-0.88^{n s)}$ & & \\
\hline Urea fertilizer (UF) & $1.95^{\star *}$ & & & \\
\hline Paddy production (PP) & & $2.34^{* *}$ & $8.33^{* * *}$ & $4.77^{\star \star \star}$ \\
\hline Household Income Surplus (HIS) & & & $-2.00^{* *}$ & \\
\hline Household Head Age(HHA) & & & $3.58^{* * *}$ & \\
\hline Financial transfers (FT) & & & $-0.75^{\mathrm{ns})}$ & $-0.49^{\mathrm{ns})}$ \\
\hline F-Statistic & $3.52^{\star *}$ & $2.12^{*}$ & $41.97^{* * *}$ & $32.28^{* * *}$ \\
\hline$R^{2}$ & 0.1153 & 0.072 & 0.7178 & 0.6294 \\
\hline
\end{tabular}

Note: $\left.{ }^{* *}\right)$ significant at $\left.1 \% ;{ }^{* *}\right)$ significant at $5 \%$; *) significant at $10 \%$; ns) not significant.

Financial transfers shows no significant on labor allocation in paddy farming. It may indicated that financial transfer from perantau do not invested in paddy farming. Maharjan et.al (2013) mentioned that migration undermines the agricultural sector which remittances are seldom invested in land or other capital inputs needed to improve the agricultural sector. 
To end the analysis variables that influence on men's hired labor with sign expected are land size (LS), paddy production (PP) and household head age (HHA). Demand of hired labor in paddy farming affected by land size and household head age. This result same as with in corn production in Nusa Tenggara Timur (Leki et.al., 2016). Paddy production will be increase when hired labor added. In other things women's hired labor can substituted women's household labor, its indicated by negatif sign in estimation result.

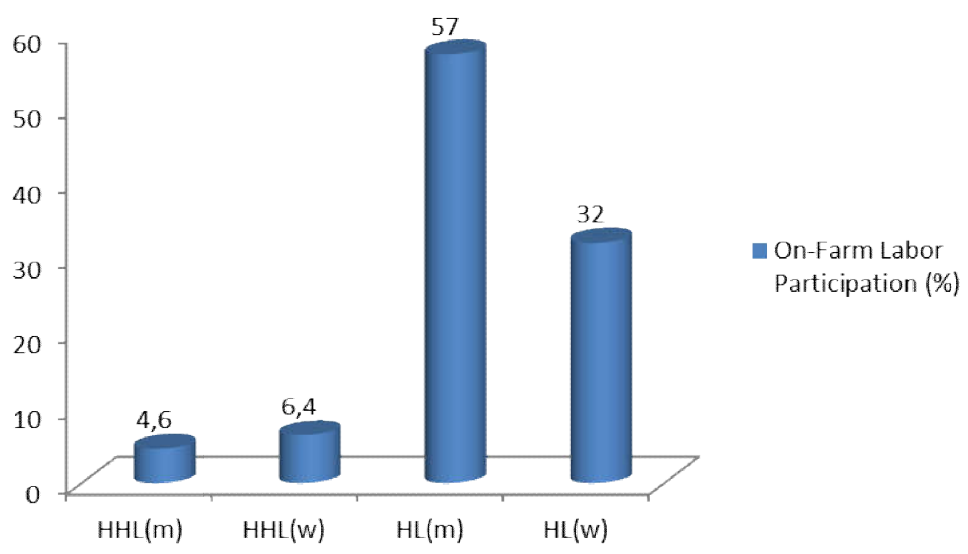

Figure 1 - On-Farm Labor Allocation in Paddy Farming

Impact Merantau On Off-Farm and Non-Farm Labor Allocation. In order to maximize labor resources, rural household prefer to labor force diversity employment. They allocate labor resources to different sectors for employment such as on-farm, off farm, non-farm activity and including migration. Motivated by the common is to increase family income and welfare, the other reason is to avoid risks.

Table 3 - Estimation Result of Equation parameter: Labor Allocation on Off-Farm and Non-Farm Activity

\begin{tabular}{|c|c|c|}
\hline \multirow{2}{*}{ Explanatory variables } & \multicolumn{2}{|c|}{ Parameter Value } \\
\hline & Off-Farm Labor & Non-Farm Labor \\
\hline Intercept & $3.71^{* * *}$ & $3.38^{\star \star \star}$ \\
\hline Men'sHousehold labor $\left(\mathrm{HHL}_{\mathrm{m}}\right)$ & $-1,29^{\mathrm{ns})}$ & $-1.13^{\mathrm{ns})}$ \\
\hline Number of perantau(NM) & $-0.46^{\mathrm{ns})}$ & $2.32^{* *}$ \\
\hline Household Income (HTI) & $5.59^{* * *}$ & \\
\hline Household expenditure(HE) & & $5.60^{\star \star *}$ \\
\hline Household Head Age(HHA) & $-3.82^{\star \star \star}$ & $-4.48^{\star \star *}$ \\
\hline Financial transfers $(\mathrm{FT})$ & & $-4.46^{* \star *}$ \\
\hline Non-farm Household labor allocation(NFL) & $-4.18^{* * *}$ & \\
\hline Household Income Surplus (HIS) & & $3.73^{* * *}$ \\
\hline Value of livestocks(VL) & & $-4.96^{\star * *}$ \\
\hline Yard size(YS) & $0.94^{\mathrm{ns})}$ & \\
\hline F-Statistic & $9.44^{\star * *}$ & $12.88^{\star \star \star}$ \\
\hline $\mathrm{R}^{2}$ & 0.2971 & 0.4040 \\
\hline
\end{tabular}

Note: ${ }^{* * *}$ ) significant at $1 \%$; ${ }^{* *}$ ) significant at $5 \%$; $)$ significant at $10 \%$; ns) not significant.

Table 3 provides a estimation of all variables used in the empirical analysis in off-farm and non-farm labor. Variable number of perantau (NM) does not significant influence off farm labor allocation. Result suggest that household income positively encouraged to increse off farm hours worked. Allocation in off farm labor affected by non-farm hours worked with negatif sign. An increasing in hours worked off-farm labor $1 \%$ may reducing non-farm activity about 4.18 hours worked. Result representing that off-farm and non-farm labor have substitute association in both. In addition value of livestocks (VL) has negatif sign and significant. Value of lifestock as determinant for off-farm activities. 


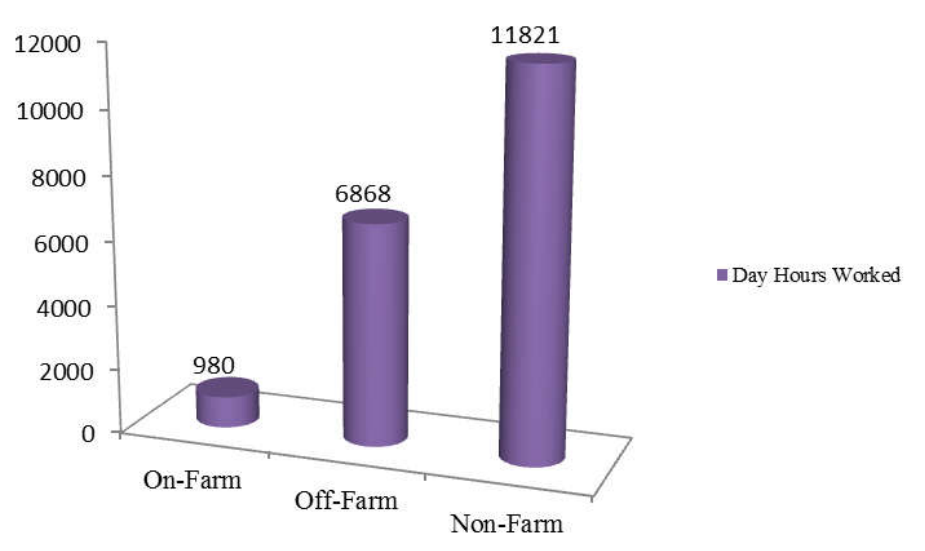

Figure 2 - Household Labor Allocation in Multiple Activity

While all dependent variables in this model simultaneously influence non-farm labor allocation. Variable number of perantau (NM) has positif sign and statistically significant. The consequence of lack of family member who merantau will increasing usage non-farm activity. Contrary to expectation, impact of financial transfers to non-farm activity has negatif sign. Meanwhile it has positif sign for income surplus. Presumably the financial transfers do not affected with direct connection to non-farm activity, but pass through income surplus.

Household expenditure (HE) has positive sign and significant. It describe that to enhancement disposable income for necessity household expenditure, they use more labor resources for non-farm activities. Finally, the labor behavior on household left behind in village which has higher level of merantau generally devote labor resources to more non-fam activities (see Figure 2).

\section{CONCLUSION AND SUGGESTIONS}

The lack of family labor caused by outmigration (merantau) in West Sumatra have the impact on more hired labor and less household labor in paddy farming. Financial transfers as a determinant of remmitance from perantau is not significant influence on demand of hired labor or off-farm activities. The results indicated that when financial transfers relatively high, peasant do not invest in crop farming and livestocks. We assume that household prefer to use it on non-farm activities such as family entrepreneurs called manggaleh, consumption goods and for more leisure. The result also suggest that merantau have to role in increasing feminisation on agriculture due to deprivation of men's labor.

The findings of this study contributions for relevant policy implications. Merantau has been cultural and natural process for Minangkabau communities. The stagnating in agricultural sector must be government concern that seeks policy attention, caused it still the major source of lifelihood for rural household. Involvement of migrant community organization such as SAS (Sulit Air Sepakat), IKTD (Ikatan Keluarga Tanah Datar) and PKDP (Persatuan Keluarga Daerah Piaman) to contribute on rural development.

\section{REFERENCES}

1. Acharya, P. Chakra and R. Leon-Gonzales. 2012. The impact of remittance on poverty and inequality: A micro-simulation study fo Nepal. GRIPS Policy Research Center. Discussion Paper: 11-26

2. Adam, R.Jr. 1996. Remittances, income disribution and rural asset accumulation. International Food Policy Institute, Washington.

3. Barnum,Howard, N. dan Lyn Squire. 1979. An Econometric Application of The Theory of The Farm-Household. Journal of Development Economics Vol.6.pp 79-102 
4. Black, Richard. 1993. Migration, return and agricultural development in the Serra do Alvao, Northern Portugal. Economic Development and Cultural Change. Vol. 41 (3). Pp.63-85.

5. Caldwell, J.C. 1968. Determinants of rural-urban migration in Ghana. Population Studies: A Journal of Demography. Vol.23 No.3, pp. 361-377.

6. Dèmurger, Sylvie. 2015. Migration and families left behind: families sthat stay behind when a member migrates do not clearly benefit. IZA World Labor 144.

7. Effendi Nursyirwan. 1999. Minangkabau markets: a picture of an indigenoue economic system. Working paper N.312. Sosiology of Development Resech Center. Southeast Asia Programm

8. Fan, Maoyang., S. Gabbard., A.A. Pena and J.M.Perloff. 2014. Why do fewer agricultural workers migrate now? Institute for Research on Labor and Employment (IRLE) Working Paper 117-14.

9. Kazt, E. 2003. The Changing Role of Mowen in The Rural Economics of Latin America. In CUREMIS II

10. Kreager Philip. 2006. Migration, social structure and old-age support networks: comparison of three Indonesian communities. Ageing Soc. Vol 26(1), pp.37-60.

11. Leki, Silverius., N.Hanani., R. Dwiastuti and B. Setiawan. 2016. Household economic decisions of corn farmers at West Timor, Indonesia. Russian Journal of Agricultural and Socio-Economic Sciences Vol.4(1),pp.74-83

12. Maharjan, Amina., S. Bauer and B. Knerr. 2013. Migration for labour and its impact on farm production in Nepal. Working Paper IV Centre for the Study of Labour and Mobility.

13. Mccarthy, N., Gero, C., Benjamin, D., Irini, M. 2006. Assessing the impact of massive out-migration on agriculture. European Journal of Development Research. Vol.21. pp. 448-470.

14. Naim, Mochtar. 1979. Merantau: Pola Migrasi Suku Minangkabau. Gadjah Mada University Press

15. Rozelle, S., J.E. Taylor dan A. deBrauw. 1999. Migration, Remittances and Productivity in China. American Economic Review Vol.89 No.2.pp287-291

16. Schmook, B dan Radel, C. 2008. Male Transnational Migration and Its Lingkages to Land-Use Change in a Southern Campeche Ejido. Journal of Latin American Geography Vol.7. No.2

17. Silfelani, T. 2009. Impact of Migration on Food Security in Chiredzi, Zimbabwe.

18. Taylor, J.E., Rozelle,S., de Brauw,A., 2003. Migration and incomes in source communities: a new economics of migration perpective from China. Economic Development and Cultural Change 52 (1), 75-101.

19. William, S. 2007. Migration in Africa: A Review of the Economic Literature on International Migration in ten Countries. Development Prospects Group The World Bank.

20. Yiqiong Chen. 2015. Analysis on resource allocation of peasant household labor force. International Business and Management Vol.11(2),pp.60-63. 